Special Issue "Physical Limnology"

Guest Edited by Prof. Adam Choiński and Prof. Mariusz Ptak

Limnol. Rev. (2020) 20, 2: 97-108

DOI 10.2478/limre-2020-0011

\title{
Exogenous shore processes in water reservoirs of Belarus
}

\author{
Viktor E. Levkevich ${ }^{1}$, Ivan Kirvel' ${ }^{2}$, Sergey I. Parfomuk ${ }^{3}$ \\ ${ }^{1}$ Belarusian National Technical University (BNTU), Nezavisimosti 65, 220013 Minsk, Republic of Belarus, \\ e-mail: fes@bntu.by \\ ${ }^{2}$ Department of Environmental Analysis, Pomeranian University in Słupsk, Partyzantów 27, 76-200 Słupsk, Poland, \\ e-mail: ivan.kirvel@apsl.edu.pl ( ${ }^{*}$ corresponding author) \\ ${ }^{3}$ Brest State Technical University, Moskovskaya, 267, 224017 Brest, Republic of Belarus, \\ e-mail: parfom@mail.ru
}

\begin{abstract}
The article presents the results of observations and research on the dynamics of exogenous erosion processes on the shores of lowland reservoirs in Belarus. Features and regularities of the dynamics of development of exogenous shores subject to abrasion-processing and an assessment of planned and profile stability of coastal slopes on the basis of proposed criteria are presented. The relationship between exogenous processes and accumulation processes was determined, the approaches and criteria for determining the stability of reservoir shores based on the hydrological regime of reservoirs and ground conditions were developed.
\end{abstract}

Key words: reservoir, shore, abrasion, processing, exogenous processes, sustainability criteria

\section{Introduction}

In Belarus, reservoirs are widely used for land reclamation, recreation, regulation of surface and river flow, fisheries, technical and drinking water supply, as well as for energy needs. Currently, there are about 150 reservoirs of various types with a total area of about $2500 \mathrm{~km}^{2}$ and a total volume of $10 \mathrm{~km}^{3}$. The length of the shoreline of reservoirs in Belarus is more than $1500 \mathrm{~km}$, of which about 320 $\mathrm{km}$ (more than 20\%) are subject to exogenous processes: processing - the abrasion of slopes. Against the background of abrasion, landslide processes can develop, for example at the Vileika Reservoir in Belarus (Fig. 1A) and the Włocławek Reservoir in Poland (Fig. 1B).

Exogenous processes that occur in the coastal zone of artificial water bodies have a significant negative impact on the surrounding territories and the functioning of many sectors of the national economy, resulting in the exclusion of land from agricultural use, the need to move residential and industrial buildings, etc. The most important issue in solving the problem of damage reduction is the prediction of the development of exogenous abrasive-erosive processes on water bodies with an assessment of the scale of their manifestation.

\section{Data and methods}

As initial data for the analysis and study of the process of destruction of the reservoirs the published materials and data of long-term field observations on the test reservoirs of Belarus (Vileika, Zaslavskoe, Lepelskoe, Chizhovskoe, Osipovichskoe, etc. - Fig. 2) and Poland (Włocławek) were used (Kaczmarek et al. 2015; Banach et al. 2013; Levkevich 2015a,b; Kirvel 1998; Kirvel and Lewkiewicz 2005). For the estimation and analysis of data profile surveys for a number of years of observations on representative characteristic areas of the reservoir shore were used. The criteria characterizing the homogeneity of parts of the shore were as follows: the form of slope, shape of the coastline in the plan, the composition of coast-forming rocks, the parameters of the hydrological regime - the characteristics of wind waves, water level regime and flow regime.

The duration of observations in reservoirs of 

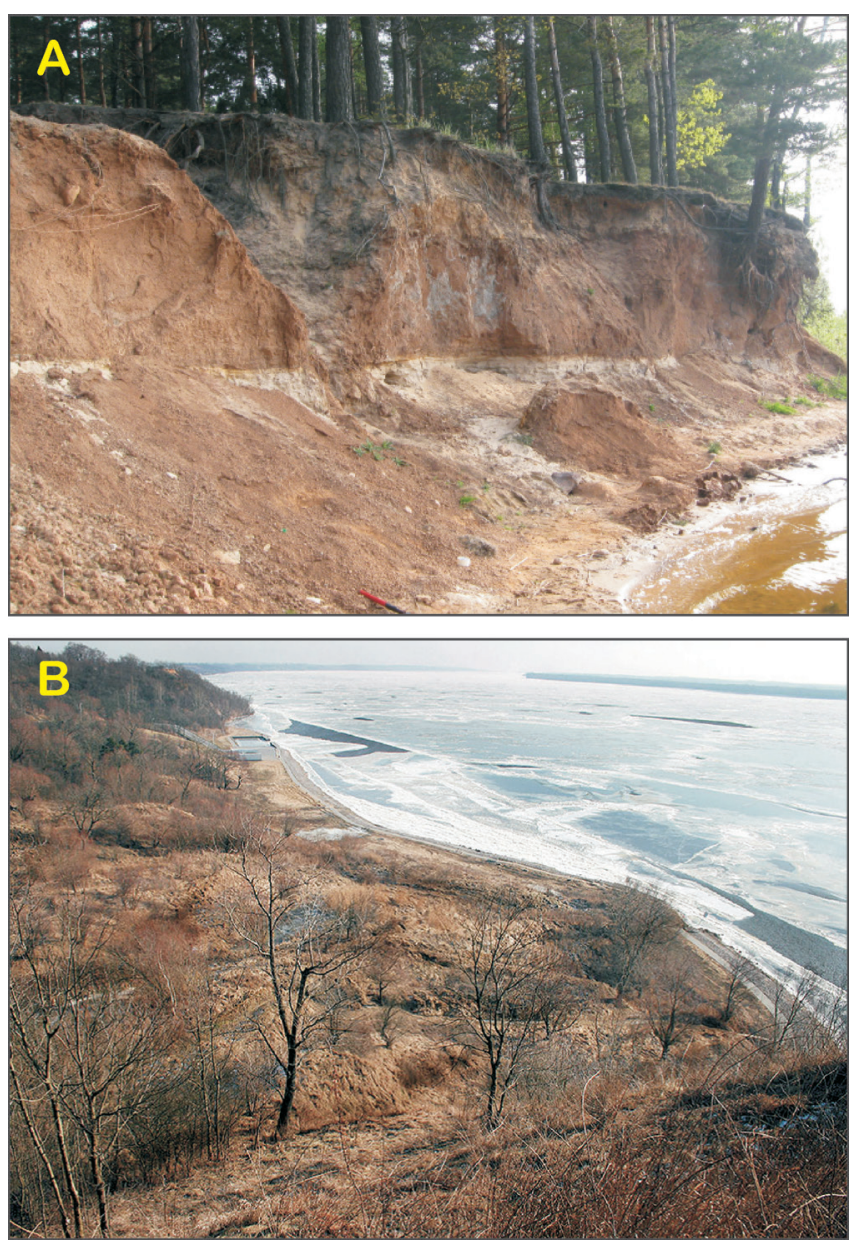

Fig. 1. Photos of abrasion - shore processing of the Vileika Reservoir, Belarus (A) and the development of landslides on the Włocławek Reservoir, Poland (B) (Banach et al. 2013; Kaczmarek et al. 2015)

Belarus ranged between 25 to 60 years (Levkevich 2015a,b), and in Polish reservoirs - more than 40 years (Kaczmarek et al. 2015; Banach et al. 2013). The total number of monitoring targets used for stationary observations of exogenous processes is more than 350. Profile and planned surveys were performed using HT and Leica NC500 levels, a laser rangefinder and a Buchnell echo sounder with reference to a reference network of observations using Leica DGPS. In recent years, the data from the multizone high-resolution satellite imagery of SPOT and the Belarusian satellite BelKA-1 were used, as well as shooting from unmanned aerial vehicles (UAVs) - quadrocopters of the DJI Phantom 3 Professional series.

\section{Results and discussion}

Observation data on a number of reservoirs in Belarus and Poland have shown that exogenous processes occurring on abrasive shore slopes depending on the composition of the soil that compose the shore have the following subtypes (Fig. 3A-C): (i) abrasive-scree (a combination of loosely connected soils). This is found in the Central and Southern parts of Belarus and Poland (Zaslavskoe, Soligorskoe, Osipovichskoe, Vileika, Włocławek reservoirs, etc.), (ii) abrasive-collapse (a combination of loosely connected soils of sandy loam) are observed at the Włocławek, Lepelskoe, Osipovichskoe reservoirs, and (iii) abrasive-landslide (the dominance of connected soils: loams, clays) are observed at the Chizhovskoe, Dubrovskoe, Lepelskoe, Włocławek and other reservoirs (Fig. 4).

Long-term observations have established that the shores of reservoirs, both in Belarus and Poland, tend to an equilibrium state in their development (Kaczmarek et al. 2015; Levkevich 2015a,b; Levkevich 2018a). The quantitative criterion for assessing the equilibrium of the shoreline is its total length, which is a function of the reservoir area. To assess the degree of approximation of the length of the reservoir shoreline to the equilibrium one, we proposed an indicator - the coefficient of development or stability of the shoreline $\left(k_{p}\right)$, which is determined by the ratio of the length of the shoreline of reservoirs subject to processing $\left(L_{a b r}\right)$ to the length of accumulative shores $\left(L_{a c c}\right)$ (Levkevich 2015a,b; Levkevich 2018b):

$$
k_{p}=L_{a b r} / L_{a c c} .
$$

When the underwater part of the of the abrasive shore shoal is formed the development of long-shore sediment flows is observed, which form various accumulative forms in the shore zone and determines the general trend of leveling the shoreline of reservoirs (Fig. 5).

It was found that the width of the shore zone exposed to $F s$ processing $\left(\mathrm{m}^{2}\right)$ in the conditions of lowland reservoirs in Central Europe is determined by the empirical dependence of the type (Levkevich 2015b):

$$
F S=\sum_{i=1}^{n}\left(S_{t L A K E}+S_{t R E S}\right) L_{a b r i},
$$

where: $S_{t L A K E}, S_{t R E S}$ - linear processing of the shore in different states of the water bodies: lakes and res- 


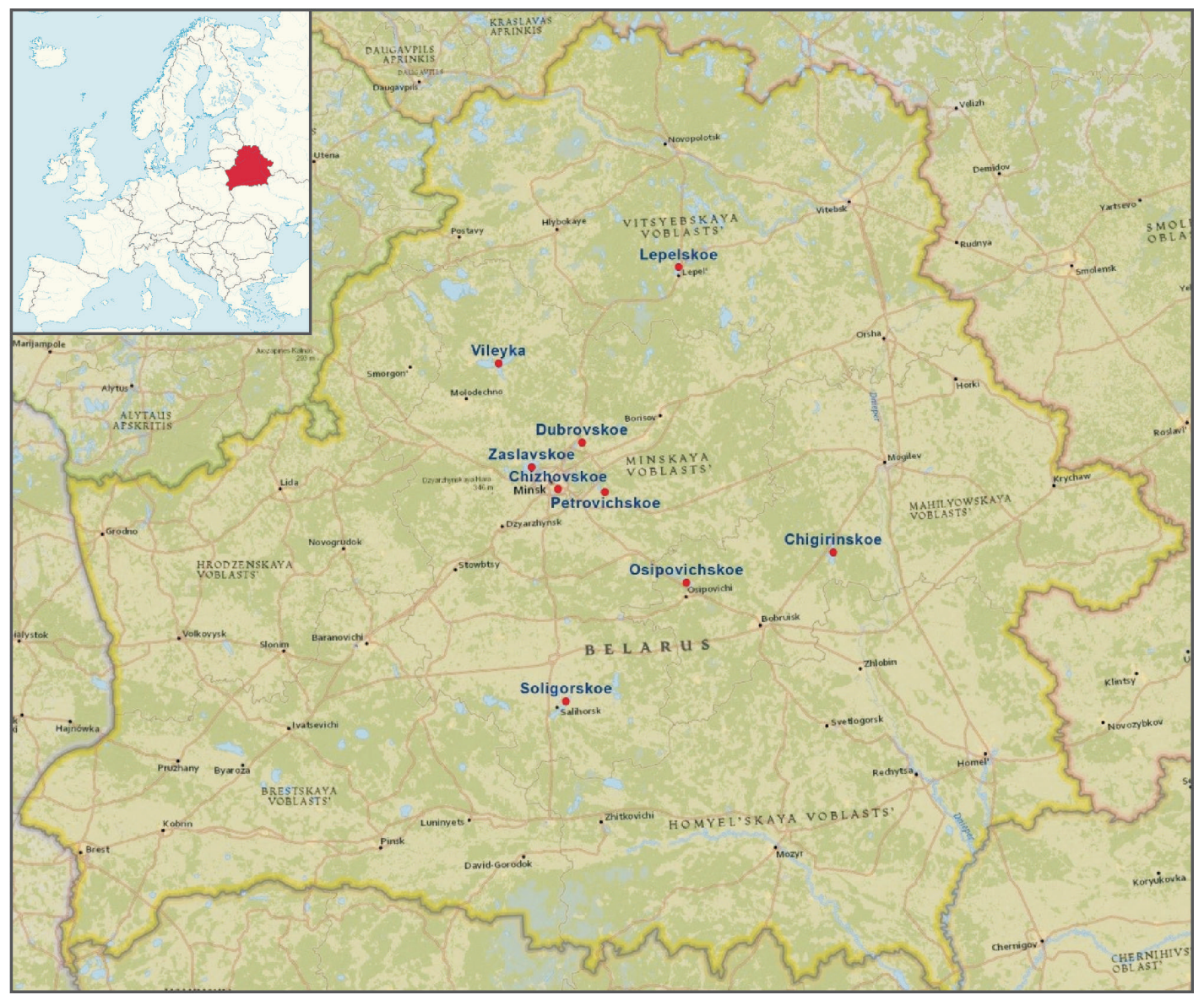

Fig. 2. Location map of the studied reservoirs in Belarus

ervoirs, $\mathrm{m} ; n$ - the number of observation stations determined by the length of the processing site and the method of observation (up to 50 observation); $L_{a b r i}$ - the length of the coastline on the $i$-th section of the shore that is subject to processing (abrasion), m.

Observations made by authors on the reservoirs of neighboring territories of the Polish-Belarusian region have shown that accumulative formations are formed exclusively from non-connected sandy material-fine-grained Sands. The material for processing the shore moving along the cut fills the volume of incoming corners, bays, small bays, river mouths and reclamation channels forming embankments (Fig. 6A). If the flow of sediment wraps around the cape-like protrusion of the coast, accumulative (fan) braids are formed on the leeward side of bays and gullies. Such formations are the most common (Fig. 6B).

Assessing the stability of the shoreline in terms of the plan, we assume that the original shoreline is a curve with alternating headlands and bays (Banach et al. 2013; Kaczmarek et al. 2015; Levkevich 2015a,b; Levkevich 2018b). One of the conditions for planned stability of the reservoir shoreline corresponding to the equilibrium stage is an expression of the form (Levkevich 2018b): $L_{a b r}=L_{a c c}$. The value of the stability coefficient $k_{P}$ can be used to assess the state of the shoreline. At $k_{\mathrm{p}} \rightarrow 1$ the shoreline tends to be balanced. In the case of $k_{\mathrm{p}}>1$ the first 10-15 years of the reservoir's existence are dominated by abrasive leveling of the slopes. Due to the fact that the coefficient $k_{\mathrm{p}}$ is proportionally related to the value of $k_{\text {tor }}$ the general and mandatory condition for an equilibrium coastline can be written as follows:

$L_{a b r} / L_{a c c}=k_{p} \rightarrow 1 \quad$ and $\quad L_{1} / L_{2}=k_{\text {tor }} \rightarrow 1$, [3]

where: $k_{\text {tor }}$ - the coefficient of curvature of the coastline equal to the ratio of $L_{1}$ and $L_{2}$ (the length of the coastline (or their segments) along the shortest straight line and actually existing respectively). 

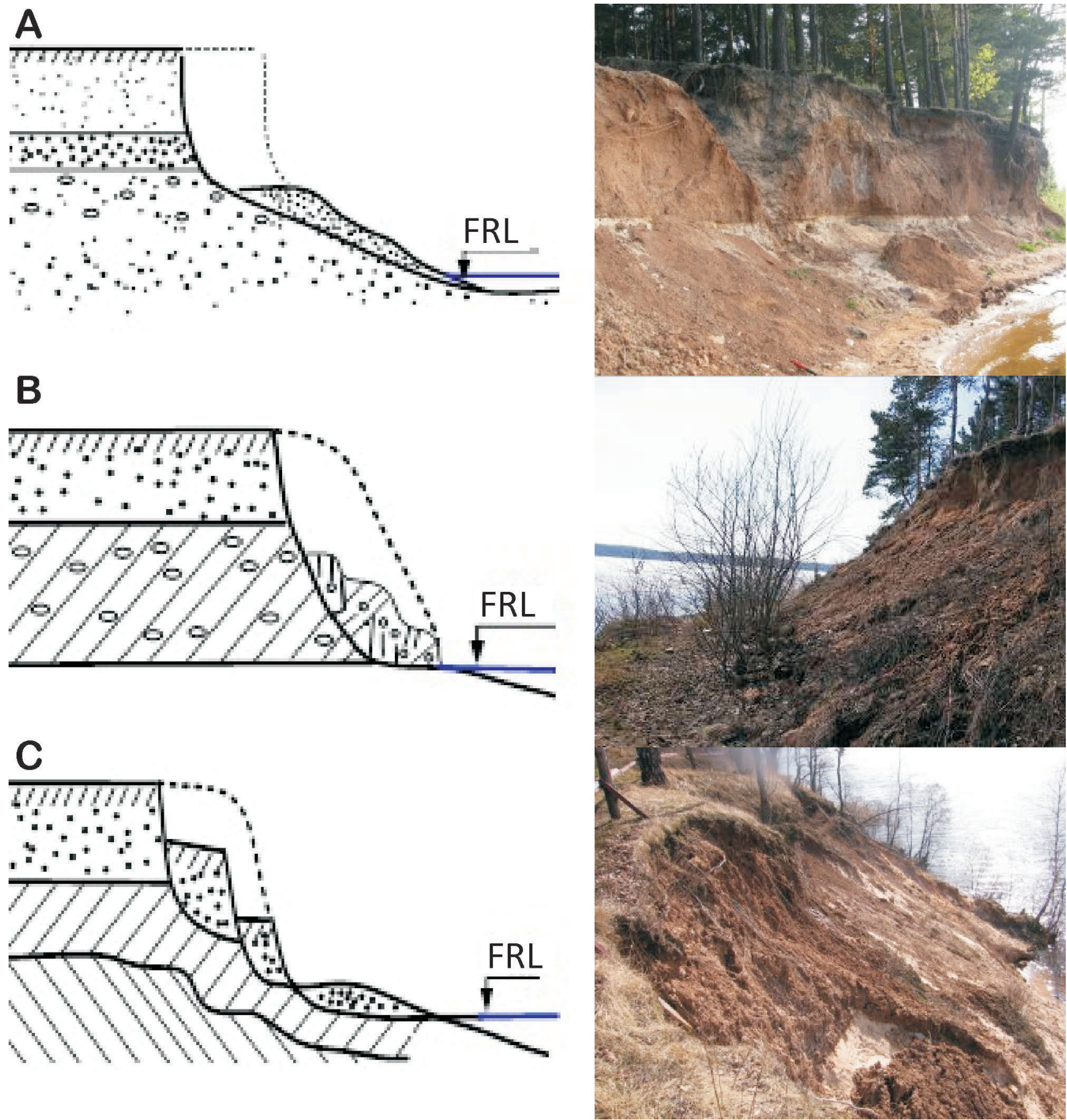

Fig. 3. Subtypes of abrasive shores (A - abrasive-scree; B - abrasive-collapse; C - abrasive-landslide) (Levkevich 2018a)

When the $k_{\mathrm{p} i}$ decreases from the initial value of the $k_{\mathrm{p} i}$ to the $k_{\mathrm{p} i+1}$ there is a change in the $k_{\text {tor }}$. Accordingly with increasing t the value of $\Delta S_{i}$ (the value of processing the shore) and equally $\Delta L_{i}$ (the value of accumulation) tend to 0 . The ratio (Eq. 3) should be observed between the erosion of capes and the introduction of bays by the processing material of coasts characterized by the values of $L_{a b r}$ and $L_{a c c}$, since with the increase of $L_{a b r}$ there is an increase in $L_{a c c}$. At later stages (when a coastal shoal is formed), the development of long-shore sediment flows occurs. Then the balance equation of the coastline exposed to abrasion at the equilibrium stage corresponding to the final period $\left(t_{f}\right)$ is represented as 


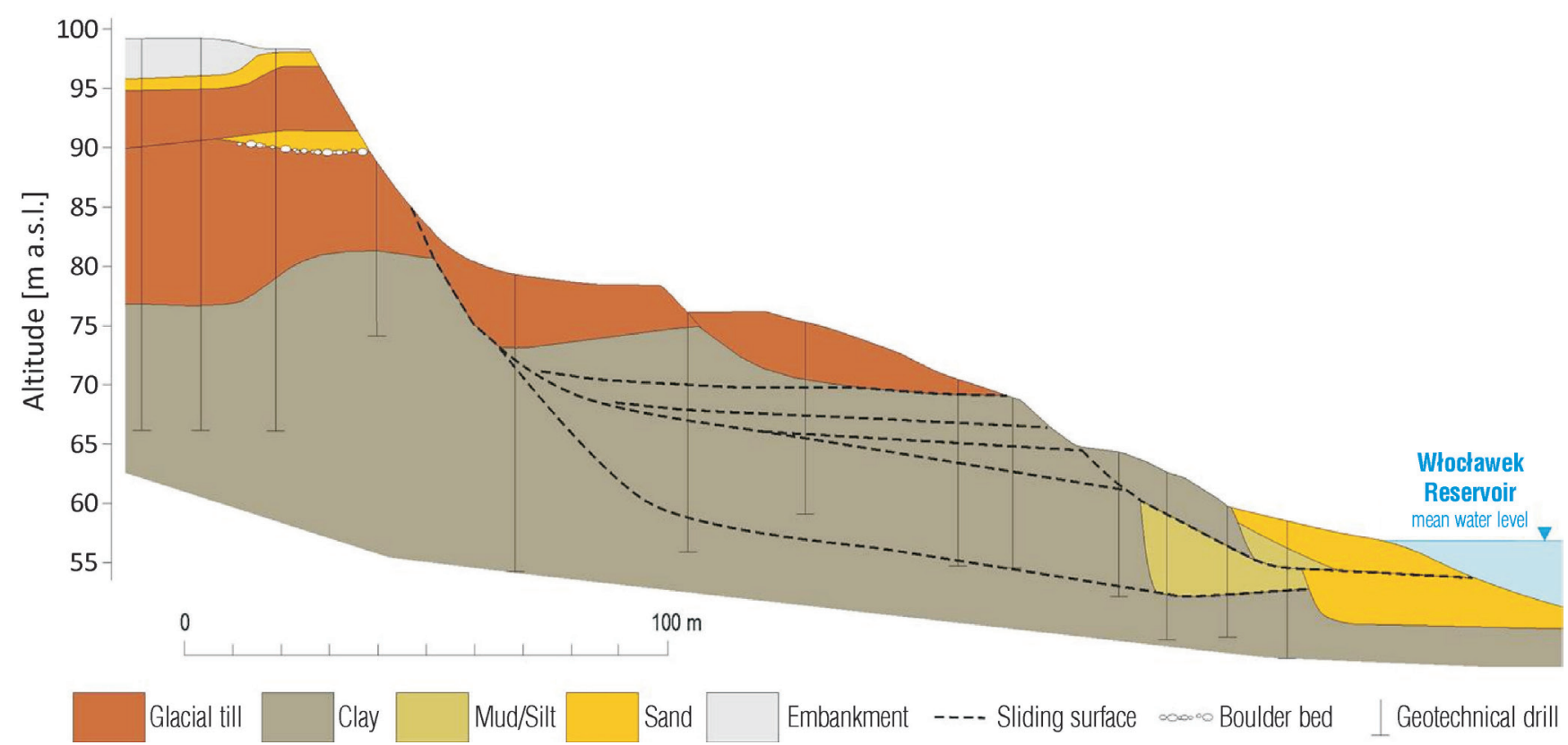

Fig. 4. Abrasive-landslide shore of the Włocławek Reservoir (Banach et al. 2013; Kaczmarek et al. 2015)

(Levkevich 2018a; Levkevich 2018b):

$$
\begin{gathered}
\int_{t_{i}}^{t_{f}}\left(\sum_{t=0}^{n} Q_{a c c}+d Q_{a c c}\right) d t= \\
=\int_{t_{i}}^{t_{f}}\left(\sum_{t=0}^{n} Q_{a b r}+d Q_{a b r}\right) d t \pm \Delta Q_{a b r},
\end{gathered}
$$

where: $\sum Q_{a c c}, \sum Q_{a b r}$ - the volume of accumulation in the underwater part of the profile of the processing material and the volume of abrasion in the above-water part of the slope respectively, $\mathrm{m}^{3}$.

The shape of the underwater part of the shore slope composed of disconnected homogeneous soils can be determined on the basis of the differential equation of deformation of the shore profile that was proposed by (Maksimchuk 1981).

Equation 4 is met when the following initial and final conditions are occuring:

$$
k_{p i}>k_{p f} \quad \text { and } \quad k_{\text {tor } i}<k_{\text {tor I }},
$$

where: $k_{p i}, k_{\text {tor } i}, k_{p,}, k_{\text {tor } f}$ - the values of coefficients for the initial $t_{i}$ and final $t_{f}$ periods of processing and accumulation respectively. The exogenous abrasive process has a damping character in time (Fig. 7) (Kaczmarek et al. 2015; Levkevich 2018a).

When analyzing the dynamics of the development of abrasives, both in the reservoirs of Belarus and Poland, it was found that the period of formation of shores subject to processing can be divided into a number of stages. In the researches of Banach et al. (2013), Levkevich (2015a,b), and Kirvel (1998) there are 3 stages of development of abrasion shores (Fig. 8): the I stage of initial intensive processing, the II stage of attenuation processing, and the III stage of stabilization of the recycling process development of a profile of dynamic balance (Levkevich 2015b; Levkevich 2018b).

A significant contribution to the consideration of issues related to determining the regularities of a stable shoreline formation in the plan has been made by a number of modern researchers: Pyshkin (1973), Shirokov (1974), Sokol'nikov (1976), Belov (1994), and Ragozin (2008). Several very important points are noted that are relevant for the studied reservoirs.

The first crucial point is that at the initial first stage of processing of shores and most other exogenous processes (landslides, karst, and river and gully erosion) destructive processes occur only within individual sections and then quite quickly cover all new spaces developing and forming large and linear zones of destruction (Ragozin 2008).

The second point is no less important. The formation of a shore shoal resistant to external influences means the transition to the second stage of development of the shore formation in the mode of 

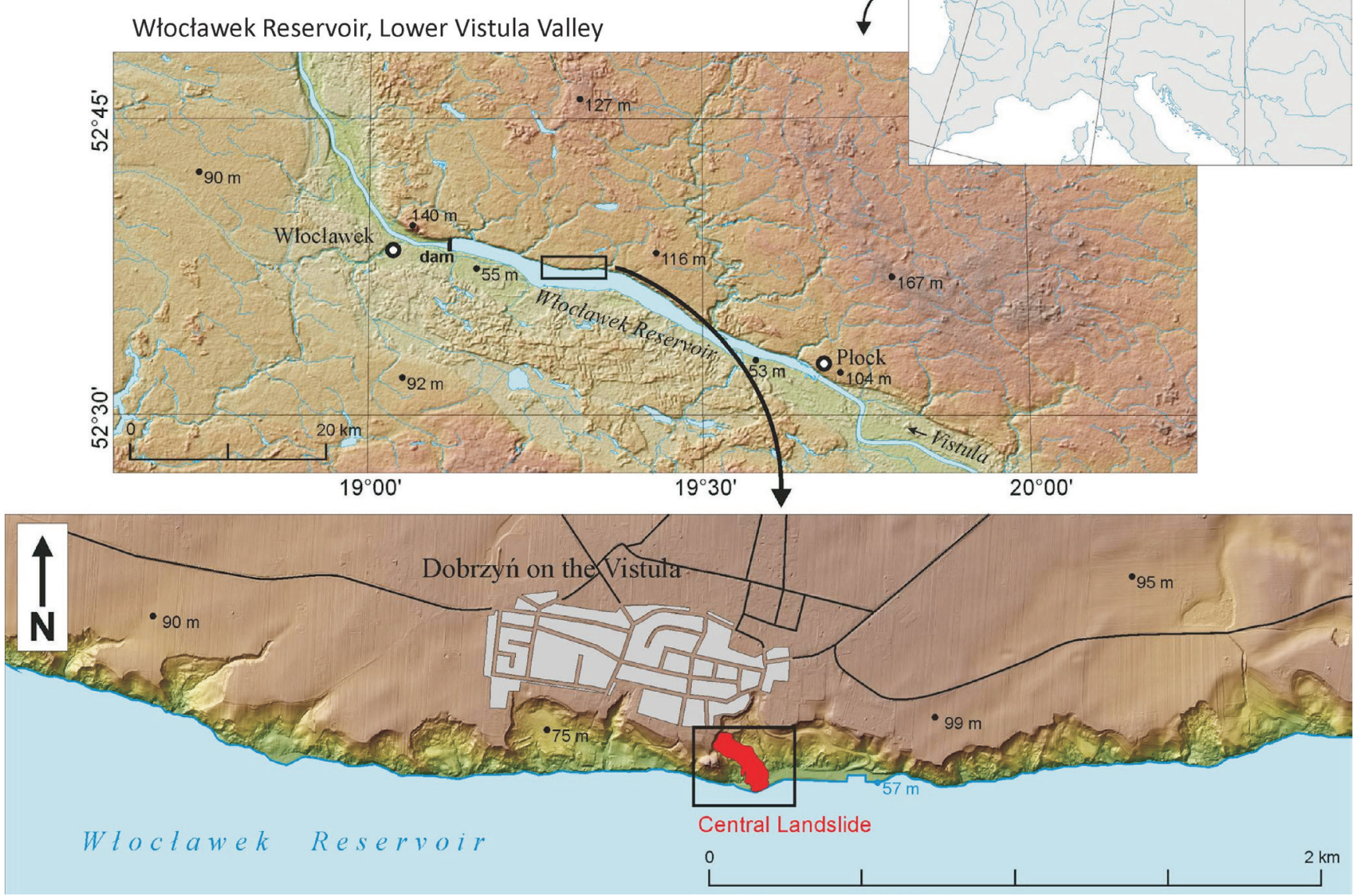

Fig. 5. Development of exogenous shore processes in the Włocławek Reservoir (Banach et al. 2013)
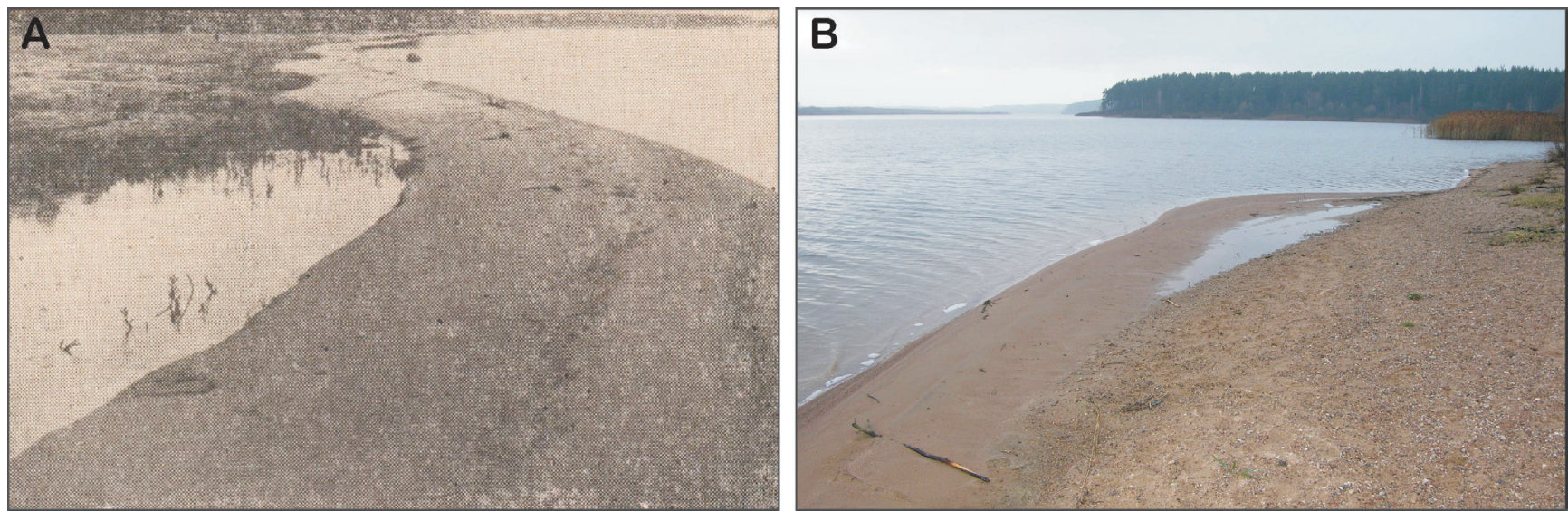

Fig. 6. Long-shore movement and accumulation of abrasive products in the coastal zone of reservoirs: Zaslavskoe (A), and Petrovichskoe (B) 


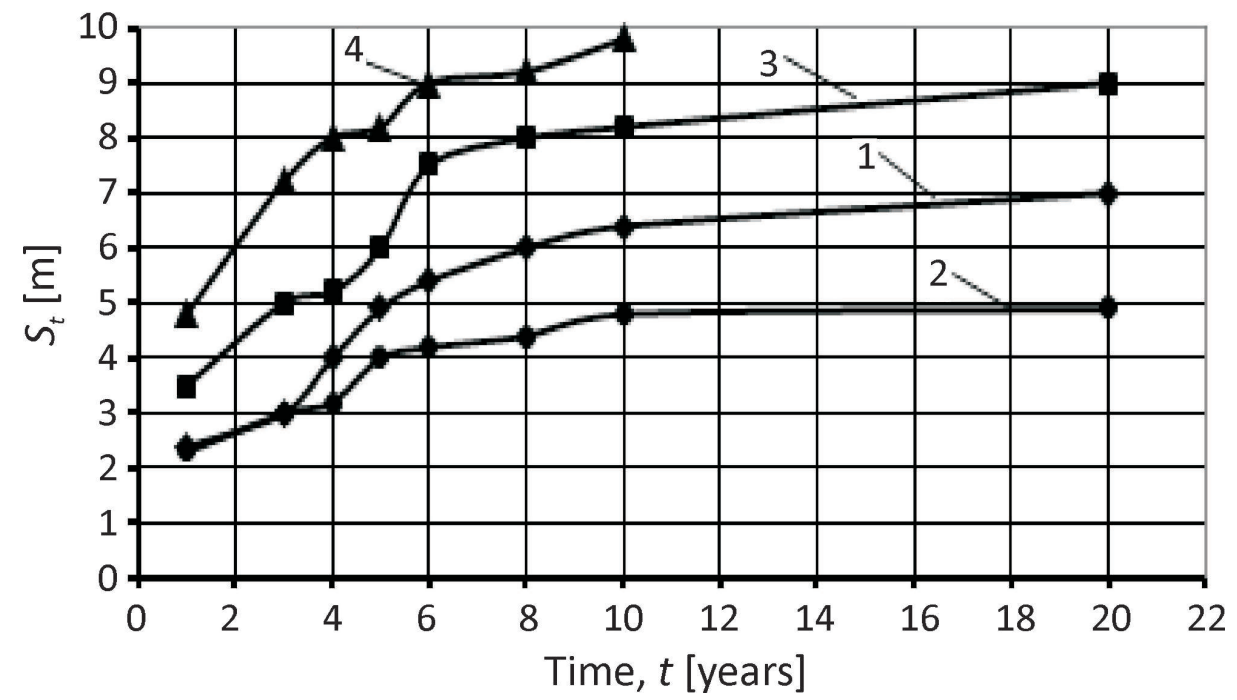

Fig. 7. Graph of dependence $S_{t}=f(t)$ for the Chizhovskoe Reservoir (1 - target \#5; 2 - target \#2; 3 - target \#3; 4 - target \#4)

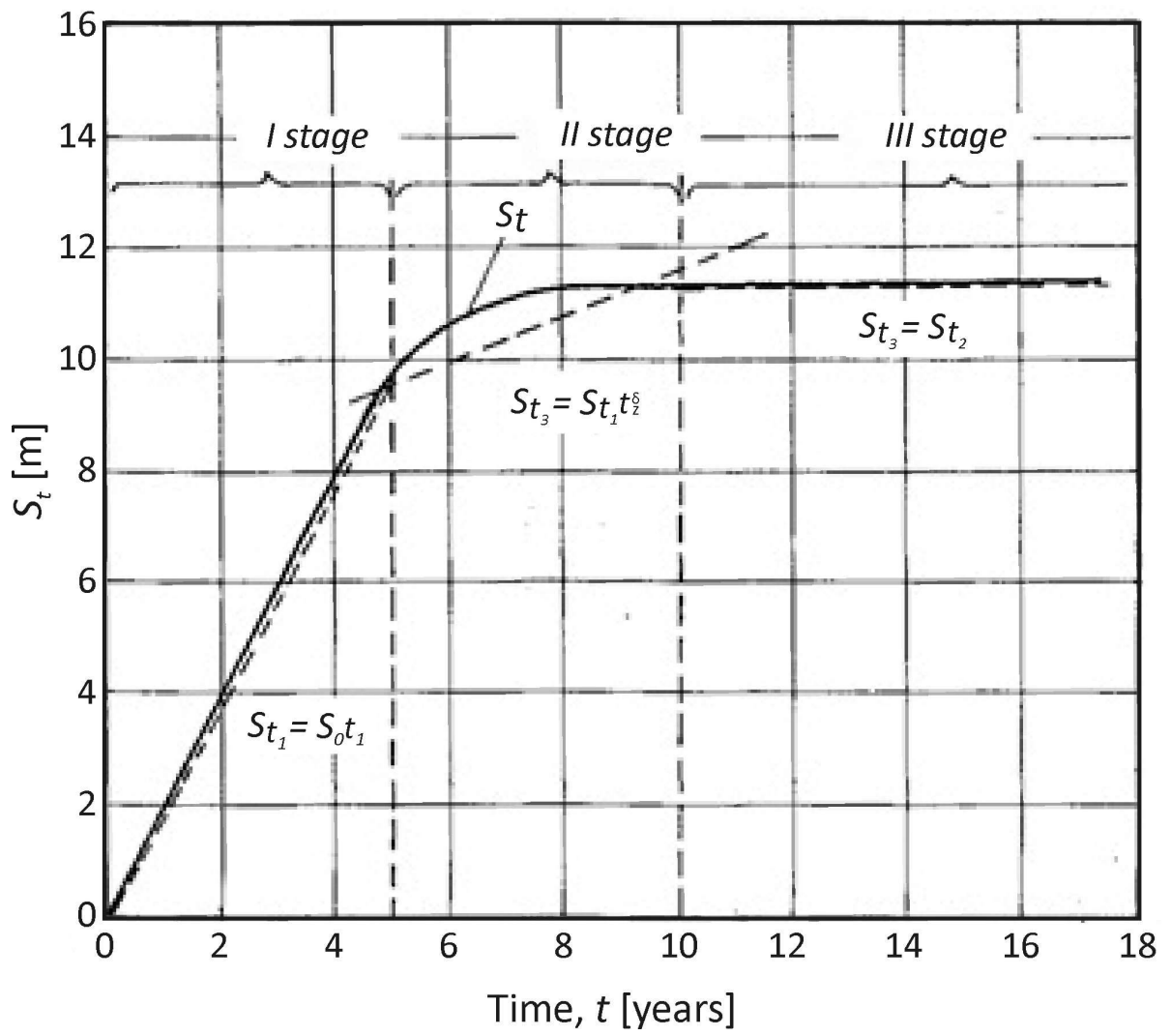

Fig. 8. Stages of development of the abrasion shores of water reservoirs in Belarus and Poland

slowing or relatively little changing in time destruction. At this stage the mechanism of self-regulation of the processing and further self-organization of shore systems becomes more active, leading to a gradual increase in the length of both abrasive and accumulative shores and the formation of stable zones of destruction, transit and accumulation of sediment.

The third point is that the last stage of processing the shores and the formation of shorelines of reservoirs is characterized by the completion of the process of formation of shore systems which theoretically should be stable.

Within the framework of these features the 
available materials of processing observations in Belarus and Poland were analyzed using research materials obtained from reservoirs located in other neighboring regions of Europe: the Czech Republic, Ukraine, and Russia.

It was found that in the conditions of Belarus and Poland in the initial period of operation of reservoirs the shoreline is characterized by high meandering which is determined by the initial relief of river valleys. The coefficient of curvature of the shoreline of the Vileika Reservoir, for example, differs significantly in its length. On the right shore this value is in the range of 1.16-2.05 with an average weighted value of 1.39 , on the left shore the values are 1.05-2.60 and 1.63, respectively.

The coefficients $k_{\text {tor }}=f(t)$ and $k_{p}=f(t)$ change over time (Fig. 9). The section of the graph $t_{\mathrm{o}} t_{1}=\Delta_{t \mathrm{I}}$ characterizes the stage of abrasive alignment of the shoreline and section $t_{1}-t_{2}=\Delta t_{\text {II }}$ shows the stage of accumulative formation. The asymmetry of the graph indicates the dominance of the first or second process in time and depends on the mode of receipt of the processing material in the reservoir and feeding the sediment flow $\Delta Q_{a b r}$ taking into account the shape of the shore slope. For the shore of a shallow shape $(H / \lambda>2$, where $\mathrm{H}$ is the depth at the shore, $\lambda$ is the wavelength of $1 \%$ of the security) abrasive asymmetry is dominant (Fig. 9A), for the shallow - accumulative asymmetry (Fig. 9B). In some cases there is normal asymmetry.

The accumulative process of the shore alignment as well as the abrasion process proceeds by stages distinguishing between three main stages: the first stage in the shore zone along with the lateral movement of sediment, the formation of shore flows is evident; the second stage is characterized by intensive growth and development of open accumulative forms; the third stage marks the formation of close accumulative forms filling of incoming angles and similar shapes, leading to the formation equilibrium of the shoreline.

The stage duration of abrasive-accumulative shore leveling generally covers a period (in the case of reservoirs with a significant difference in levels) of 25-30 years, e.g. the Vileika, Zaslavskoe, Lepelskoe, and Soligorsk Reservoirs, and the Grodno hydroelectric power station. At low water level fluctuations in reservoirs this period lasts $15-20$ years (e.g. the Chigirinskoe, Osipovichskoe, and Petrovichskoe Reservoirs). Similar data were obtained in the Włocławek Reservoir (Banach et al. 2013; Kaczmarek et al. 2015).

In general, it should be noted that the shore development of reservoirs in Belarus and Poland occurs according to the same patterns and approximately on the same scale. The fact is the transition from one shore type to another (in particular, from abrasive to accumulative) and then to neutral with some asynchrony depending on a combination of local conditions that testify to the stages of the process.

Along with the planned balance of the shoreline there is a profile balance of the shore slope. In this case the ratio of profile elements is expressed as a dependency of the form $Q_{t} / S_{t}=f\left(\mathrm{~B}_{\mathrm{ut}} / \mathrm{B}_{\mathrm{st}}\right)$, where $\mathrm{B}_{u t}, \mathrm{~B}_{s t}$ are the width of the underwater and surface parts of the shore shoal, respectively. The ratio of $S_{t}$ and $\mathrm{B}_{\mathrm{ut}}$ in the country's lowland reservoirs (which are classified as small) is within the range of $0.80-0.96$, in contrast to large reservoirs where it is $0.48-0.77$. The stability criterion $\Pi_{y}$ for shores composed of disconnected soils is also an important parameter that determines the overall state of the abrasive shore (Levkevich 2018b).

A soil element with volume $W$ and area $F$ that is in extreme equilibrium under the influence of wind waves on a shore shoal below the wave destruction zone is considered (Fig. 10). The main impact on the soil mass is caused by the hydraulic pressure of the wave flow $P_{w}$ which leads to the movement of the material from the slope along the profile.

Long-distance transport of soil particles in the form of a sediment stream is caused by the presence of two conditions: a developed wide underwater part of the shore shoal and a wind wave that is obliquely approaching the edge of the front at an angle of $\theta$. This makes it possible to represent the $P_{w}$ in the form of two components: a transverse $P_{w y}$ and a longitudinal $P_{w x}$, i.e. a long-range one. In addition, the vertical weighing component $\left(P_{w z}\right)$ presents and affects the stability of the soil mass. This component is balanced by gravity $(G)$ and the rolling force component is not taken into account further. The main force exerted on the soil element is the hydraulic pressure created by the wave flow when it moves along the shore shoal (Fig. 10). The pressure of the wave flow on the sediment particle created by the bottom velocity $v_{\max }$ and its components - the longitudinal $P_{w x}$ and the transverse 
A

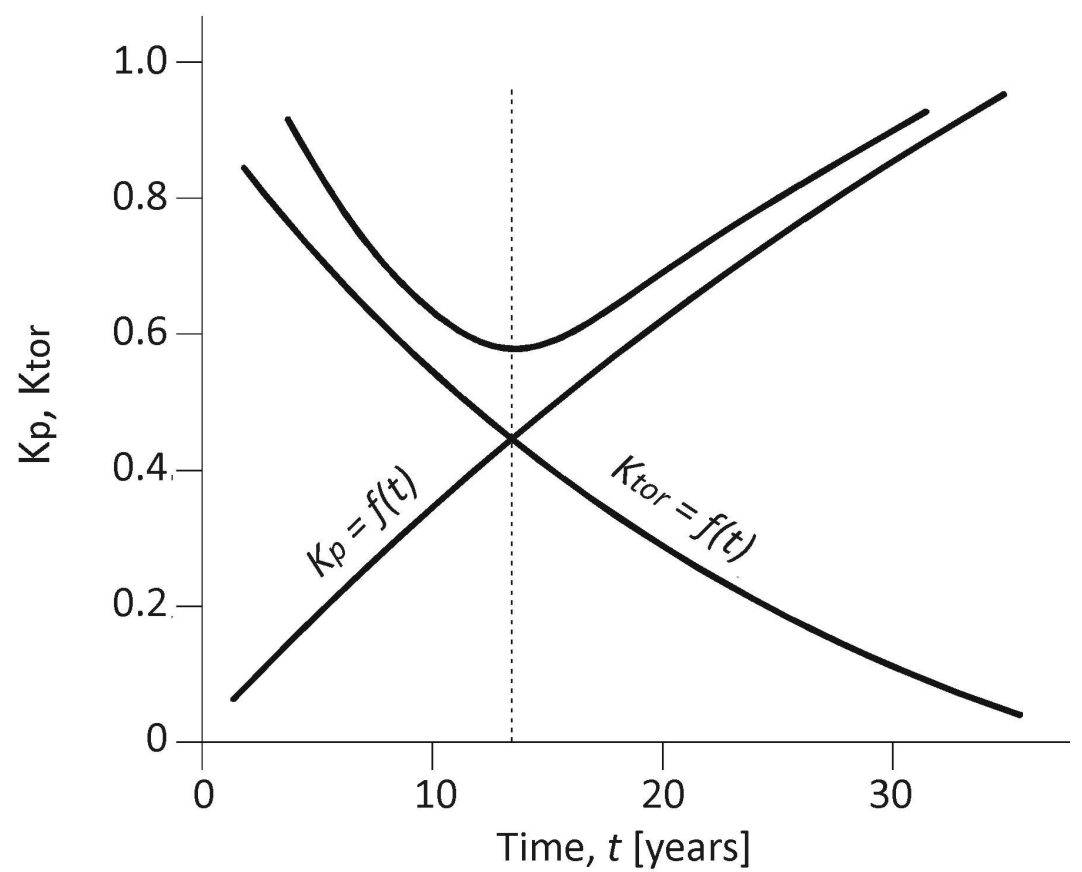

B

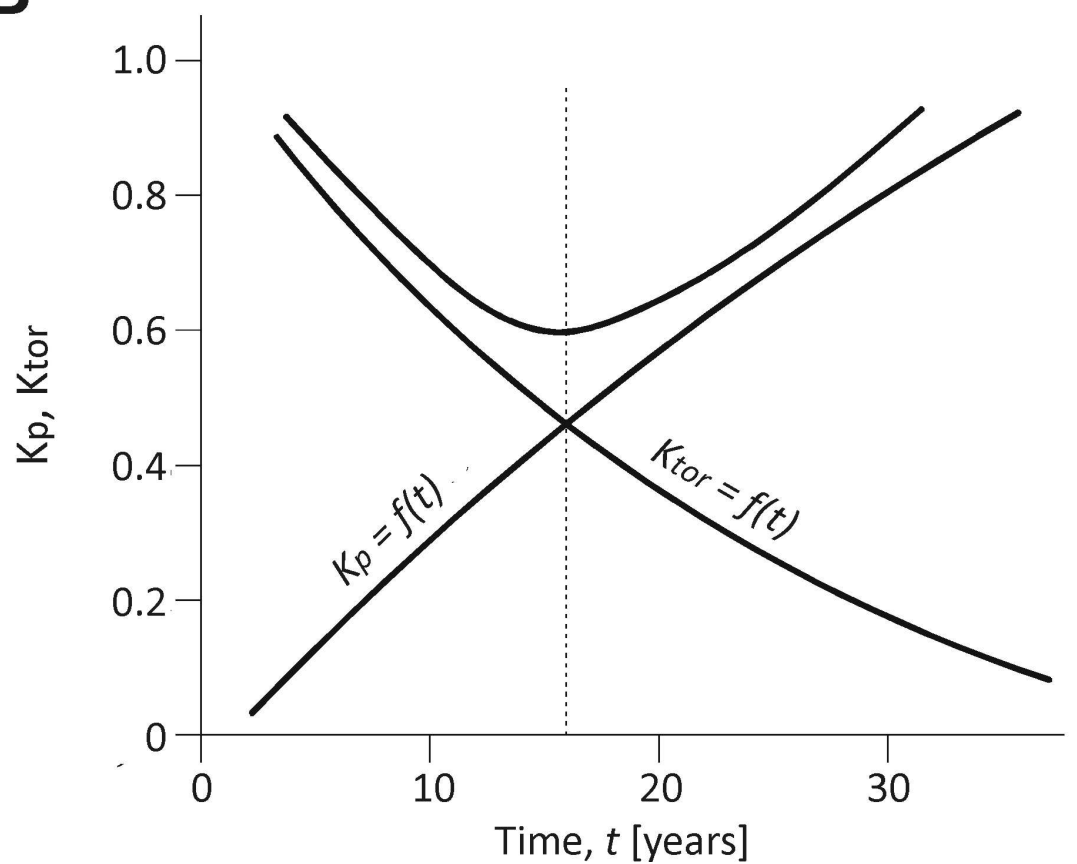

Fig. 9. Time change of $k_{t o r}=f(t)$ and $k_{p}=f(t)$ coefficients (A - abrasive asymmetry; B - accumulative asymmetry)

$P_{w y}$ are equal to (Levkevich 2018b; Mihnevich and Levkevich 2016):

$$
\begin{gathered}
P_{w x}=a_{x} F_{y} \gamma_{w} v_{\text {max }}^{2} / 2 g, P_{w y}= \\
=a_{y} F_{x} \gamma_{w} v_{\text {max }}^{2} / 2 g .
\end{gathered}
$$

Then the resultant force $P_{w}$ of the transverse and longitudinal components has the following form:

$$
P_{w}=\left(P_{w x}^{2}+P_{w y}^{2}\right)^{0.5} \text {. }
$$


Empirical and laboratory studies of a number of authors on the study of the regime of bottom wave speeds, as well as their comparison with the calculated ones, have shown that they almost coincide with the velocity of the channel flow $\left(v_{\max }=\right.$ $\left.v_{\tau}\right)$. This is confirmed by the researches of Johnson (1919), Munk and Traylor (1947), Putnam et al. (1949), Longinov (1963), and Aibulatov (1966). Therefore,

$$
\left.v_{\max }=\left(\pi h_{w} n\right) /\{[\pi \lambda h(4 \pi H / \lambda)] / \mathrm{g}]\right\}^{0.5},
$$

where: $h_{w}$ - the calculated wave height (in meters); $\lambda$ - the wave length (in meters); $g$ - the acceleration of gravity $\left(\mathrm{m} \mathrm{s}^{-2}\right) ; \mathrm{H}$ - the depth at the outer edge of the shoal (in meters); $n$ - the roughness coefficient (Levkevich 2018b; Maksimchuk 1981).

Taking the projection area of the soil element volume $W$ on the horizontal, vertical and perpendicular to the resultant $P_{w}$ plane equal to $F_{x}=F_{y}=F$ respectively (Levkevich 2018b; Mihnevich and Levkevich 2016) and substituting the $v_{\max }$ value from Eg. 8 we get:

$$
\begin{gathered}
P_{w}=\alpha_{0} F \gamma_{w} v_{\max }^{2} / 2 g= \\
=\left(0.5 \alpha_{0} F \gamma_{w} \pi h_{w}{ }^{2} n^{2}\right) / \lambda s h(4 \pi H / \lambda) .
\end{gathered}
$$

The shifting force is determined by the following expression:

$$
\begin{gathered}
N_{s}=\left[\left(\gamma_{0}^{2} \mathrm{~W}^{2} \sin ^{2} \alpha+0.25\left(\alpha_{0} F \gamma_{w} \pi\right)^{2}\left(h_{w} n\right)^{4}\right.\right. \\
\left.\left.\cos ^{2} \Theta\right) / \lambda^{2} s h^{2}(4 \pi H / \lambda)\right]^{0.5}
\end{gathered}
$$

The holding force $N_{h}$ is determined by the sum of the forces of friction and adhesion of the soil in the water. Given that the shore component of motion of the material processing in the form of sediment may occur only in the presence of shore shoals of sufficient width and wind waves to the water's edge at an angle $\Theta$ (Fig. 10) an amendment that takes into account the angle of approach of waves to the shore was introduced:

$$
N_{h}=\gamma_{0} W f \cos \alpha \cos \Theta .
$$

where: $f$ is the coefficient of internal friction for disconnected soils (Maksimchuk 1981).

The ratio of the values $N_{s}$ and $N_{h}$ is a criterion for stability of the longitudinal equilibrium profile. The equilibrium equation can be written as $N_{h}=N_{s}$, and then as:

$\gamma_{0} W f \cos \alpha \cos \Theta=\left[\left(\gamma_{0}{ }^{2} \mathrm{~W}^{2} \sin ^{2} \alpha+0.25\left(\alpha_{0} F \gamma_{w} \pi\right)^{2}\right.\right.$

$$
\left.\left.\left(h_{w} n\right)^{4} \cos ^{2} \Theta\right) / \lambda^{2} s h^{2}(4 \pi H / \lambda)\right]^{0.5} \text {. }
$$

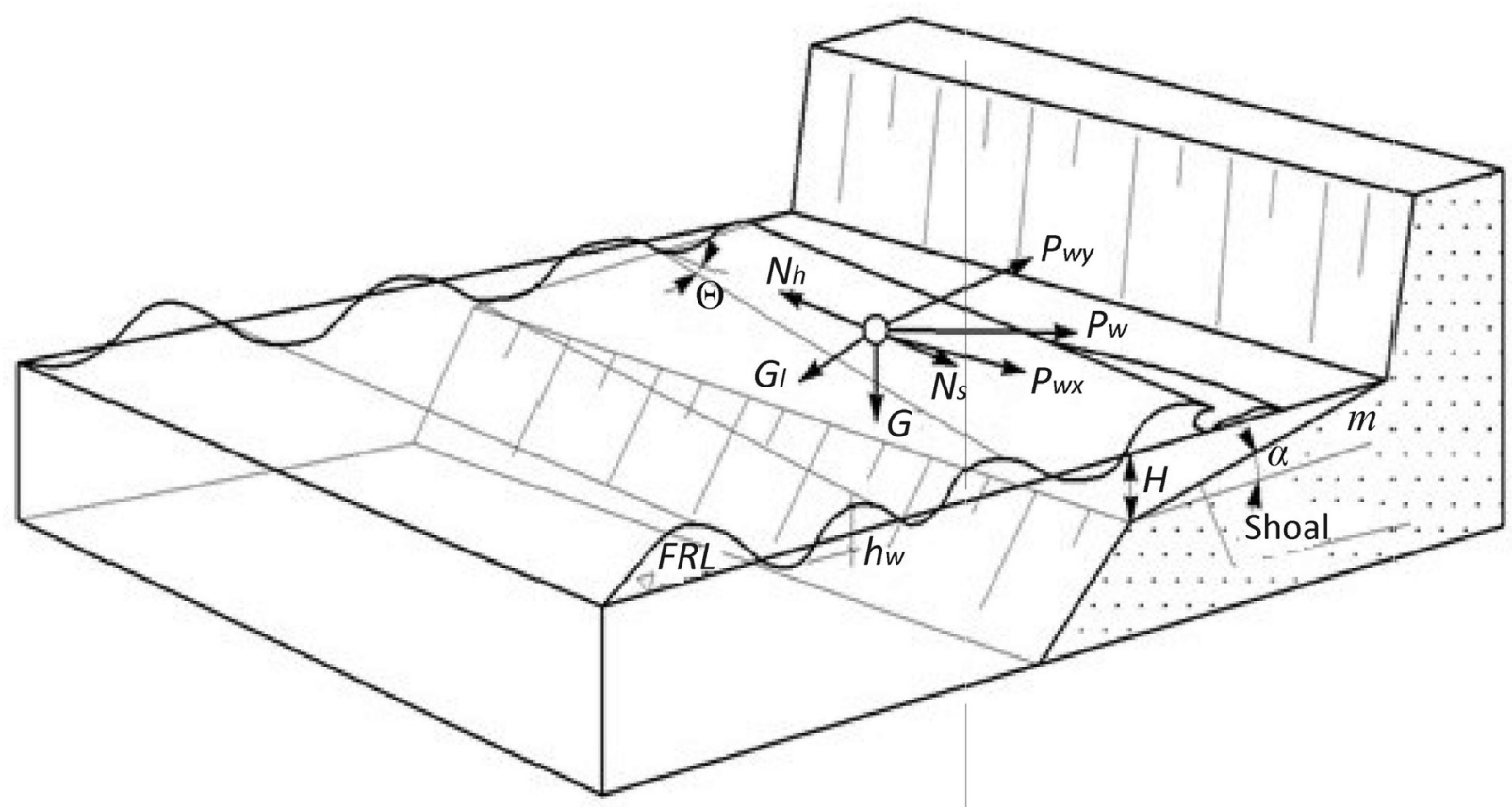

Fig. 10. The forces action diagram on the soil element on the shore shoal (Maksimchuk 1981) 
Dividing both parts of the Equation 12 by expression $(F \sin \alpha \cos \Theta)$, and taking into account that $\left(1+m^{2}\right)=\left(1 / \sin ^{2} \alpha\right)$ you will get:

$$
\begin{gathered}
\gamma_{0} d f m=\sqrt{\frac{\gamma_{0}^{2} d^{2}}{\cos ^{2} \Theta}+\frac{0,25\left(a_{0} \gamma_{\hat{a}} \pi\right)^{2}\left(h_{\hat{a}} n\right)^{4}\left(1+m^{2}\right)}{\lambda^{2} s^{2} \frac{4 \pi H}{\lambda}}}, \\
\text { If }\left(\gamma_{0} d / \cos \Theta\right)=\xi_{1} \text {, then: } \\
\alpha_{0} \gamma_{w} \pi\left(h_{w} n\right)^{2}\left(1+m^{2}\right)^{0.5} / \lambda s h(4 \pi H / \lambda)=\xi_{2} .
\end{gathered}
$$

Then the stability criterion $\Pi_{y}$ is equal to:

$$
\Pi_{y}=\left(\gamma_{0} d f m\right) /\left(\xi_{1}^{2}+0.25 \xi_{2}^{2}\right)^{0.5} \text {. }
$$

If $\Pi_{y} \geq 1$ then the shore profile and shoreline correspond to the equilibrium form of the dynamic equilibrium profile. Otherwise, when $\Pi_{y}<1$, the shore is in the stage of intensive processing and formation.

\section{Conclusions}

The results of a comprehensive analysis of data from long-term observations of the shore formation process in the studied reservoirs are as follows:

- exogenous processes occurring on abrasive shore slopes in reservoirs of Belarus and Poland have 3 subtypes: abrasive-scree, abrasive-collapse, and abrasive-landslide;

- the shores of reservoirs tend to an equilibrium state in their development in both countries;

- the relationship between exogenous processes and accumulation processes that determine the conditions and dynamics of the formation of the dynamic equilibrium profile of abrasive shores and stabilization of the shoreline was determined;

- the criterion $\Pi_{y}$ for determining the stability of reservoir shores based on the hydrological regime of reservoirs and ground conditions was developed.

\section{References}

Aibulatov N.A., 1966, Issledovanie vdol'beregovogo peremeshcheniia pesachnykh nanosov $\mathrm{v}$ more (Investigation of the coastal movement of sand deposits in the sea), Izd. Nauka, Moskva, 159 pp (in Russian).

Banach M., Kaczmarek H., Tyszkowski S., 2013, Rozwój osuwisk w strefie brzegowej sztucznych zbiorników wodnych na przykładzie osuwiska centralnego w Dobrzyniu nad Wisłą, Zbiornik Włocławski (Development of landslides in the shore zones of reservoirs, as exemplified by the central landslide at Dobrzyń-onthe-Vistula, Włocławek reservoir), Prz. Geogr. 85(3: 397-415 (in Polish, English summary).

Belov D.M., 1994, Osnovnye polozheniia teorii morfodinamicheskikh system beregovoi zony moria (The main provisions of the theory of morphodynamic systems of the coastal zone of the sea), Izd. RAN, Moskva, 56 pp (in Russian).

Johnson D.W., 1919, Shore processes and shoreline development, Wiley, New York 584 pp.

Kaczmarek H., Tyszkowski S., Banach M., 2015, Landslide development at the shores of a dam reservoir (Włocławek, Poland), based on 40 years of research, Environ. Earth Sci. 74: 4247-4259.

Kirvel I., 1998, Oddziaływanie stawów na środowisko przyrodnicze (Impact of ponds on the environment), [in:] Mat. Konf. Nauk. "Przyrodnicze i techniczne problemy gospodarowania wodą dla zrównoważonego rozwoju obszarów wiejskich" (Proc. of the Scientific Conference "Natural and technical problems of water management for sustainable rural areas development”), Wydaw. SGGW, Warszawa, 127-133 (in Polish).

Kirvel I., Lewkiewicz V., 2005, Miejscowe oszacowanie procesów brzegowych i ryzyko abrazji na nadbrzegu zbiorników wodnych i stawów Białorusi (Local estimation of bank processes and risk of abrasion on the shores of Belarusian reservoirs and ponds), [in:] Jankowski K., Ilczuk M., Dąbrowski R. (eds), Kierunki badawcze młodzieży akademickiej. Nauki przyrodnicze (Research fields of academic youth. The natural sciences), Wydaw. AP, Siedlce, 231-235 (in Polish).

Levkevich V.E., 2015a, Dinamicheskaia ustoichivost' beregov vodokhranilishch Belarusi (Dynamic stability of the shores of reservoirs in Belarus), Izd. Pravo i ekonomika, Minsk, 305 pp (in Russian).

Levkevich V., 2015b, Dinamika beregovykh protsessov ruslovykh, nalivnykh i ozernykh vodokhranilishch Belarusi (Dynamics of shore processes of channel, bulk and lake reservoirs of Belarus), Izd. Pravo i ekonomika, Minsk, $200 \mathrm{pp}$ (in Russian).

Levkevich V., 2018a, Dinamika formirovania beregov malykh ravninnyh vodohranilishch (Dynamics of the formation of the shores of small reservoirs), LAMBERT Academic Publishing, Riga, 149 pp (in Russian).

Levkevich V, 2018b, Hydro-morphodynamica prybrezhnoi zony vodohranilishch GES Belarusi (Hydro-morphodynamics of the shore zone of reservoirs of Hydroelectric Power Plants of Belarus), Izd. Pravo i ekonomika, Minsk, 139 pp (in Russian).

Longinov V.V., 1963, Dinamika beregovoi zony besprilivnykh morei (Dynamics of the coastal zone of non-tidal seas), Izd. Akad. Nauk SSSR, Moskva, 379 pp 
(in Russian).

Maksimchuk V.L., 1981, Ratsional'noe ispol'zovanie i okhrana beregov vodokhranilishch (Rational use and protection of the shores of reservoirs), Izd. Budivel'nik, Kiev, 112 pp (in Russian).

Mihnevich E., Levkevich V.E., 2016, Ustoichivost beregov vodokhranilishch pri formirovanii provilia dinamicheskogo ravnoveciia $v$ nesviaznykh gruntakh (Stability of reservoir shores while forming profile of dynamic equilibrium in incoherent soils), Melioratsiia 78(4): 18-23 (in Russian).

Munk W.H., Traylor M.A., 1947, Refraction of ocean waves: a process linking underwater topography to beach erosion, J. Geol. 55(1): 1-26.

Putnam T.A., Munk W.H., Traylor M.A., 1949, The prediction of longshore currents, Trans. AGU 30(3): 337 345.

Pyshkin B.A., 1973, Dinamika beregov vodokhranilishch
(Dynamics of the waterside of reservoirs), Izd. Nauk. dumka, Kiev, 416 pp (in Russian).

Ragozin A., 2008, Obshchie zakonomernosti formirovaniia i kolichestvennaia otsenka prirodnykh riskov na territorii Rossii (General patterns of formation and quantitative assessment of natural risks in Russia), Voprosy Analiza Riska 1(2-4): 28-47 (in Russian).

Sokol'nikov Yu.N., 1976, Inzhenernaia morfodinamika beregov i ee prilozhenie (Coastal engineering morphodynamics and its application), Izd. Nauk. Dumka, Kiev, 228 pp (in Russian).

Shirokov V.M., 1974, Formirovanie beregov i lozha krupnykh vodokhramilishch Sibiri (Formation of the coast and bed of large reservoirs in Siberia), Izd. Nauka, Novosibirsk, 172 pp (in Russian). 